\title{
Effect of ammonium/nitrate ratio on pak choi (Brassica chinensis L.) photosynthetic capacity and biomass accumulation under low light intensity and water deficit
}

\author{
H.Q. SHANG and G.M. SHEN ${ }^{+}$ \\ Key Laboratory of Plant Biology, Department of Life Sciences, Heze University, Heze 274015, Shandong, China
}

\begin{abstract}
We conducted a hydroponic experiment in order to study effects of the ammonium/nitrate ratio $(0: 15,5: 10,7.5: 7.5$, and 10:5) on photosynthetic characteristics and biomass accumulation in Brassica chinensis under low light intensity and water stress. Results showed that net photosynthetic rate, transpiration rate, intrinsic water-use efficiency, stomatal conductance, intercellular $\mathrm{CO}_{2}$ concentration, effective quantum yield of PSII photochemistry, electron transport rate, and nonphotochemical quenching were lower in the treatment (low light intensity and water deficit) than those in the control, whereas stomatal limitation increased. Minimum fluorescence, maximal quantum yield of PSII photochemistry, and photochemical quenching were largely unchanged. Pigment contents first increased and then decreased as the ammonium/nitrate ratios were altered, with significant differences between treatment and control observed at all ratios except for 10:5. Biomass first increased slightly and then decreased both in treated and control plants. Results suggest that economic losses caused by extreme conditions can be minimized by a proper adjustment of the ammonium/nitrate ratio.
\end{abstract}

Additional key words: chlorophyll fluorescence; electron transport rate; nitrate reductase; $\mathrm{NH}_{4}^{+}, \mathrm{NO}_{3}^{-}$; stomatal conductance; water-use efficiency.

\section{Introduction}

Water, light conditions, and nitrogen concentrations are the main factors influencing vegetable crop production. During winter and spring seasons, light has a great influence on vegetable formation, with most vegetable crops requiring strong or intermediate light exposure (Shen 2016). Weak light hinders vegetable growth (Hou et al. 2002), while water stress, which impedes photosynthesis, is the main reason for declining vegetable crop production in arid and semiarid areas (Deng et al. 2006, El Bassam 2010, Brittain Jr. 2016). Nitrogen nutrition is an important regulator of crop growth and photosynthetic productivity. Excess nitrogen supplementation causes agricultural, ecological, and environmental pollution and prevents improvement of vegetable crop yield and quality (Oerke et al. 1994, Gill et al. 2011, Hirel et al. 2011, Xu and Zhou 2005, 2006).

Extensive research has been carried out on physio- logical mechanisms related to the use of fertilizer to regulate water utilization (Angus and van Herwaarden 2001, Deng et al. 2006, Cramer et al. 2009, Yan et al. 2008, Waraich et al. 2011). When soil is used as a culture medium for vegetable growth, ammonium nitrogen $\left(\mathrm{NH}_{4}{ }^{+}-\mathrm{N}\right)$ fertilizer performs better than nitrate nitrogen $\left(\mathrm{NO}_{3}^{-}-\mathrm{N}\right)$ (Lastra et al. 2009, Yu et al. 2015). Under hydroponic conditions, in contrast, a $\mathrm{NO}_{3}{ }^{-}-\mathrm{N}$ source is better, however, supplementation with a large concentration of nitrate-based fertilizer can readily lead to the accumulation of $\mathrm{NO}_{3}^{-}-\mathrm{N}$, which is unfavorable for effective plant nitrogen uptake (Gigon and Rorison 1972, Yan et al. 2008). Studies have shown that the addition of specific amounts of $\mathrm{NH}_{4}^{+}-\mathrm{N}$ to nutrient solution can increase crop biomass and chlorophyll (Chl) contents (Ruiz-Martinez et al. 2012, Wang et al. 2009). In pak choi (Brassica chinensis L.), low light intensities decrease the

Received 28 October 2016, accepted 28 July 2017, published as online-first 13 April 2018.

${ }^{+}$Corresponding author; phone: +86 5305525804, e-mail: gmshen@tzc.edu.cn

Abbreviations: $\mathrm{Car}$ - carotene; $\mathrm{Chl}$ - chlorophyll; $C_{\mathrm{i}}$ - intercellular $\mathrm{CO}_{2}$ concentration; $E$ - transpiration rate; ETR - electron transport rate; $F_{m}$ - maximum fluorescence; $F_{0}$ - minimum fluorescence; $F_{s}$ - fluorescence at stable state; $F_{v}$ - variable fluorescence; $\mathrm{F}_{\mathrm{v}} / \mathrm{F}_{\mathrm{m}}$ - maximal quantum yield of PSII ; $g_{\mathrm{s}}$ - stomatal conductance; $\mathrm{L}_{\mathrm{s}}$ - stomatal limitation; NPQ - nonphotochemical quenching; $\mathrm{NR}$ - nitrate reductase; $\mathrm{PEG}$ - polyethylene glycol; $P_{\mathrm{N}}$ - net photosynthetic rate; $\mathrm{qP}$ - photosynthetic quenching; WUE - intrinsic wateruse efficiency $\left(=P_{\mathrm{N}} / g_{\mathrm{s}}\right) ; \Phi_{\mathrm{PSII}}-$ effective quantum yield of PSII photochemistry; $\Psi_{\mathrm{w}}-$ water potential.

Acknowledgements: This work was supported by Natural Science Foundation of Shandong Province, China (ZR2016CM19). and the "5136" Talent Project of Heze University. 
photosynthetic rate and reduce leaf area, which leads to a decline in biomass and inhibition of growth (Zhang et al. 2007). Light, nitrogen, and their cross-regulation affect leaf pigment contents, the ratios of various pigments, leaf fluorescence characteristics, and energy conversion. A study using the nitrogen-tracer technique to investigate the effect of $\mathrm{NH}_{4}{ }^{+}-\mathrm{N}$ and $\mathrm{NO}_{3}{ }^{-}-\mathrm{N}$ nutrition on nitrate accumulation in vegetables in vivo revealed that increasing the ratio of $\mathrm{NH}_{4}{ }^{+}-\mathrm{N}$ reduced nitrate accumulation in vegetables (Ai et al. 2002). Under shade conditions, the relative proportions of $\mathrm{NH}_{4}^{+}-\mathrm{N}$ and $\mathrm{NO}_{3}{ }^{-}-\mathrm{N}$ have been found to affect crop yields and quality as well as nitrogen metabolism (Leleu et al. 2000, Vyas 2004, Kuang et al. 2014).

\section{Materials and methods}

Plant material and culture conditions: Experiments were carried out during the 2016 cabbage-growing season (late March to early May) in the greenhouse of the Zijingang Campus Experimental Station, Zhejiang University, Hangzhou, China $\left(30^{\circ} 46^{\prime}-30^{\circ} 50^{\prime} \mathrm{N}, 119^{\circ} 46^{\prime}-\right.$ $\left.119^{\circ} 48^{\prime} \mathrm{E}\right)$. Seeds of pak choi (Brassica chinensis L.), cultivar Hangzhou Youdonger, were germinated under the same conditions as described in Shen (2016). On 12 April, 18-d-old seedlings were transplanted into plastic pots containing $7 \mathrm{~L}$ of Hoagland-Arnon nutrient solution for further experiments.

Imposition of stress: Stress experiments were performed using four $\mathrm{NH}_{4}{ }^{+}-\mathrm{N} / \mathrm{NO}_{3}{ }^{-}-\mathrm{N}$ ratios, namely, 0:15, 5:10, 7.5:7.5, and 10:5, with the total nitrogen concentration maintained at $15 \mathrm{mmol} \mathrm{L}^{-1}$ and with $7 \mu \mathrm{mol}$ (dicyanamide) $\mathrm{L}^{-1}$ added as a nitrification inhibitor. Stress conditions consisted of exposure to $32 \%$ of full sunlight (established by placing a layer of shade cloth $1 \mathrm{~m}$ above plants) and 25 g (PEG 6,000) $\mathrm{L}^{-1}\left(\Psi_{\mathrm{w}}=-0.1671675 \mathrm{MPa}\right.$, Michel and Kaufmann 1973). Full sunlight exposure and no PEG $6,000\left(\Psi_{\mathrm{w}}=0 \mathrm{MPa}\right)$ were used as the control. Concentrations of different ions in the Hoagland-Arnon nutrient solution were adjusted to maintain constant ion contents. Concentrations of essential nutrients in all treatments were $7 \mathrm{mmol}(\mathrm{K}) \mathrm{L}^{-1}, 10 \mathrm{mmol}(\mathrm{Ca}) \mathrm{L}^{-1}, 2 \operatorname{mmol}(\mathrm{Mg}) \mathrm{L}^{-1}$, $2 \mathrm{mmol}(\mathrm{P}) \mathrm{L}^{-1}, 0.02 \operatorname{mmol}(\mathrm{Fe}) \mathrm{L}^{-1}, 46 \mu \operatorname{mol}(\mathrm{B}) \mathrm{L}^{-1}$, $9.2 \mu \operatorname{mol}(\mathrm{Mn}) \mathrm{L}^{-1}, 0.32 \mu \operatorname{mol}(\mathrm{Cu}) \mathrm{L}^{-1}, 0.76 \mu \mathrm{mol}(\mathrm{Zn}) \mathrm{L}^{-1}$, and $0.5 \mu \mathrm{mol}(\mathrm{Mo}) \mathrm{L}^{-1}$. The solution was continuously aerated during the day time with an aerobic pump. The $\mathrm{pH}$ of the nutrient solution was checked daily and adjusted as needed with $0.5 \mathrm{~mol}(\mathrm{HCl}$ or $\mathrm{NaOH}) \mathrm{L}^{-1}$ to maintain a value of approximately 6.5 . The nutrient solution was replaced weekly. Each treatment consisted of five replicates.

Sampling and biomass determination: Pak choi plants were harvested $30 \mathrm{~d}$ after transplanting. The plants were removed from the nutrient solution, washed with distilled water, and surface-blotted with absorbent paper. The plants were cut at the base to separate shoots from roots. The shoots
The aim of this study was to find the optimal ratio of $\mathrm{NH}_{4}{ }^{+}-\mathrm{N}$ to $\mathrm{NO}_{3}{ }^{-}-\mathrm{N}$ in a nutrient solution to relieve water and light stresses on vegetable crop production and reduce $\mathrm{NO}_{3}{ }^{-} \mathrm{N}$ contents in vegetables. To accomplish this goal, pak choi was cultivated under similar nitrogen contents using different proportions of $\mathrm{NH}_{4}{ }^{+}-\mathrm{N}$ and $\mathrm{NO}_{3}{ }^{-}-\mathrm{N}$ in the nutrient solution. The effects of these different proportions on pak choi leaf photosynthetic characteristics, fluorescence parameters, and biomass accumulation were measured under various water- and light-stress conditions. Our findings should contribute to a better understanding of reasonable water and fertilizer management practices for vegetable production.

were weighed and the values recorded as fresh mass (FM).

Nitrate content and nitrate reductase (NR) activity: Nitrate content was measured according to GB/T-5009.332010 (Determination of nitrite and nitrate in food of China). Nitrate reductase (NR, E.C.1.6.6.1) activity was measured in vitro as described by Leleu et al. (2000) with modifications as follows. Accurately weighed $0.5 \mathrm{~g}$ portions of fresh specimens were immersed in liquid nitrogen and ground to a powder over an ice bath. After addition of $4 \mathrm{~mL}$ of extraction buffer (containing $0.1211 \mathrm{~g}$ cysteine and $0.0372 \mathrm{~g}$ EDTA per $100 \mathrm{~mL}$ of $0.025 \mathrm{~mol} \mathrm{~L}^{-1}$ phosphate buffer, $\mathrm{pH} 8.7$ ), the homogenate was ground and then centrifuged for $15 \mathrm{~min}\left(2,200 \times g\right.$ at $\left.4^{\circ} \mathrm{C}\right)$. The resulting supernatant was used as the enzyme extract.

A mixture of $0.4 \mathrm{~mL}$ of the enzyme extract, $1.2 \mathrm{~mL}$ of phosphate buffer (containing $0.2 \mathrm{mM} \mathrm{KNO}_{3}, \mathrm{pH} 7.5$ ), and $0.4 \mathrm{~mL}$ of $0.2 \% \mathrm{NADH}$ solution was incubated in a water bath for $30 \mathrm{~min}$ at $25^{\circ} \mathrm{C}$. (A similar mixture with $0.4 \mathrm{~mL}$ of phosphate buffer substituted for the NADH served as the control.) After incubation, $1 \mathrm{~mL}$ of $1 \%$ sulfanilamide was added to terminate immediately the reaction, which was followed by the addition of $1 \mathrm{~mL}$ of $0.02 \%$ naphthyl ethylene amine solution. After staining for $15 \mathrm{~min}$ and centrifugation for $15 \mathrm{~min}\left(2,200 \times g\right.$ at $\left.4^{\circ} \mathrm{C}\right)$, the O.D. of the solution was measured at $540 \mathrm{~nm}$ (UV2600/2700, Shimadzu, Japan). The activity of NR was expressed per gram of protein extracted from fresh mass (FM) of plant materials in $\mathrm{nmol} \mathrm{min}^{-1} \mathrm{~g}^{-1}$ (protein) or (FM).

Photosynthetic rate, pigment contents and Chl fluorescence: On 12 May, after 30-d treatment, plant photosynthetic rate, pigment contents, and $\mathrm{Chl}$ fluorescence parameters were measured. Photosynthetic rate was determined according to the method of Maroco et al. (2002). Briefly, photosynthesis was measured from 8:00 to 11:30 h using a $L i-6400$ portable photosynthetic apparatus ( $\mathrm{Li-Cor} 6400$, Lincoln, NE, USA) equipped with a red and blue LED light source under the following conditions: a leaf temperature of $23 \pm 1^{\circ} \mathrm{C}$, relative humidity of $40 \pm 2 \%$, $\mathrm{CO}_{2}$ concentration of $400 \pm 5 \mu \mathrm{mol} \mathrm{mol}{ }^{-1}$, and leaf indoor 
light intensity of $800 \pm 1 \mu \mathrm{mol}$ (photon) $\mathrm{m}^{-2} \mathrm{~s}^{-1}$. Three to six fully expanded upper leaves per plant were used to determine net photosynthetic rate $\left(P_{\mathrm{N}}\right)$, transpiration rate $(E)$, stomatal conductance $\left(g_{\mathrm{s}}\right)$, and intercellular $\mathrm{CO}_{2}$ concentration $\left(C_{\mathrm{i}}\right)$. Stomatal limitation $\left(\mathrm{L}_{\mathrm{s}}\right)$ was calculated as $\left(1-C_{\mathrm{i}} / C_{\mathrm{a}}\right) \times 100 \%$, where $C_{\mathrm{a}}$ was the air $\mathrm{CO}_{2}$ concentration. Water-use efficiency (WUE) was calculated as $\mathrm{WUE}=P_{\mathrm{N}} / E$.

Pigments in plant samples were determined by microcolumn high performance liquid chromatography (HPLC) (De Las Rivas et al. 1989), with $90 \%$ acetone. Chl $a$ was determined at $649.5 \mathrm{~nm}, \mathrm{Chl} b$ at $664.5 \mathrm{~nm}$, and Car at $452.1 \mathrm{~nm}$. Chl fluorescence determination was carried out according to the method of Schreiber et al. (1986) in a $\mathrm{Li}$-Cor 6400-40 fluorescence leaf chamber ( $\mathrm{Li}$-Cor 6400-40, Lincoln, NE, USA) from 8:00 to 11:30 h. Fluorescence parameters of pak choi leaves were measured at the lightadapted state using three to six fully expanded upper leaves. From 19:00 to 21:00 h, dark fluorescence para-

\section{Results}

Biomass: Statistically significant differences in biomass were observed between control and treatments at all $\mathrm{NH}_{4}{ }^{+}-$ $\mathrm{N} / \mathrm{NO}_{3}{ }^{-} \mathrm{N}$ ratios except for 10:5 (Fig. 1). Biomass of treated plants under the four nitrogen ratios was reduced by $46.8,55.3,54.5$, and $58.7 \%$ compared with the control, which indicates that low light density and water deficit had profound effects on biomass accumulation in the studied plants. When the $\mathrm{NH}_{4}{ }^{+}-\mathrm{N} / \mathrm{NO}_{3}{ }^{-}-\mathrm{N}$ ratio was $5: 10$, plant biomass was relatively higher than that under the other nitrogen conditions, with control and treated plant biomass values of $53.1 \pm 3.13$ and $23.7 \pm 1.43 \mathrm{~g}(\mathrm{FM})$ per plant, respectively. Plants exposed to $10: 5 \mathrm{NH}_{4}{ }^{+}-\mathrm{N} / \mathrm{NO}_{3}{ }^{-} \mathrm{N}$ had the lowest biomass accumulation, with control and treatedplant biomass recorded as $36.6 \pm 3.14$ and $15.1 \pm 3.04 \mathrm{~g}(\mathrm{FM})$ per plant, respectively. The biomass reduction in the control group was $30.1 \%$ [theoretical maximum biomass = $56.23 \mathrm{~g}(\mathrm{FM})$ per plant, Table 1], while that in the treatment group was $36.3 \%$ [theoretical maximum $=25.23 \mathrm{~g}(\mathrm{FM})$ per plant, Table 1], implying that the combination of low light, water deficit, and high ammonium concentration was not conducive to the accumulation of biomass.

Nitrate content and NR activity: Water and light stress had a strong influence on NR activity in leaves, which meters were determined after acclimating leaves to darkness for $30 \mathrm{~min}$. Measured parameters included basic fluorescence $\left(\mathrm{F}_{0}\right)$, maximum fluorescence yield $\left(\mathrm{F}_{\mathrm{m}}\right)$, variable fluorescence $\left(\mathrm{F}_{\mathrm{v}}\right)$, maximum PSII intrinsic light energy conversion efficiency $\left(\mathrm{F}_{\mathrm{v}} / \mathrm{F}_{\mathrm{m}}\right)$, potential activity $\left(\mathrm{F}_{\mathrm{v}} / \mathrm{F}_{0}\right)$, and coefficient of photochemical quenching $\left(\mathrm{q}_{\mathrm{P}}\right)$. The following parameters were then calculated based on the measured data: leaf photosynthetic electron transport quantum efficiency, namely, $\Phi_{\text {PSII }}=\left(\mathrm{F}_{\mathrm{m}}{ }^{\prime}-\mathrm{F}_{\mathrm{s}}\right) / \mathrm{F}_{\mathrm{m}}{ }^{\prime}$, relative electron transfer rate $(\mathrm{ETR})=\Phi_{\mathrm{PSII}} \times \mathrm{PAR} \times 0.84 \times 0.5$, and the nonphotochemical quenching (NPQ) coefficient $=$ $\left(\mathrm{F}_{\mathrm{m}}-\mathrm{F}_{\mathrm{m}}{ }^{\prime}\right) / \mathrm{F}_{\mathrm{m}}{ }^{\prime}$ (Živčák et al. 2014).

Statistical analysis: Statistical analyses were performed in SPSS 16.0. Results from analysis of variance (ANOVA) and post-ANOVA Duncan's test were considered significant at the 0.05 probability level. All of the measurements were performed five times, and the means and calculated standard deviations (SD) are reported.

suggests that the addition of appropriate amounts of ammonia is an effective measure to reduce nitrate uptake. In both treated and control plants, the lowest nitrate content and the highest NR activity was observed at a $\mathrm{NH}_{4}{ }^{+}-\mathrm{N} / \mathrm{NO}_{3}{ }^{-}-\mathrm{N}$ ratio of 5:10 (Fig. 2).

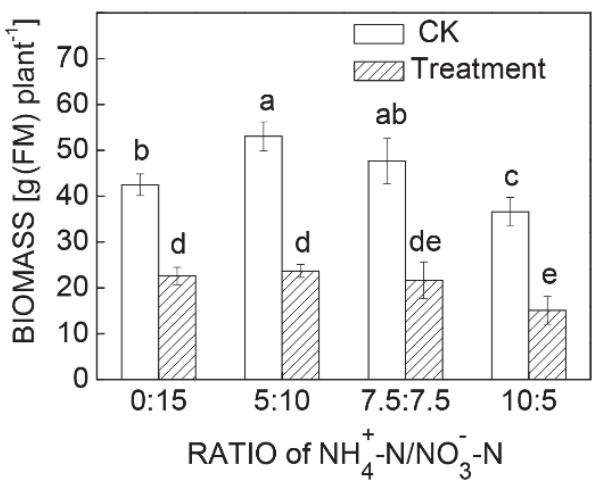

Fig. 1. Effects of $\mathrm{NH}_{4}{ }^{+}-\mathrm{N} / \mathrm{NO}_{3}{ }^{-}-\mathrm{N}$ ratio on the biomass in leaves of pak choi under low light intensity and water stress. CK - full sunlight with no PEG 6,000; the treatment at $32 \%$ full sunlight with $25 \mathrm{~g}(\mathrm{PEG} 6,000) \mathrm{L}^{-1}$. Lowercase letters mean statistically significant differences in 0.05 level $(P<0.05)$, the same in the following illustrations. $n=5$.

Table 1. Effects of $\mathrm{NH}_{4}{ }^{+}-\mathrm{N} / \mathrm{NO}_{3}{ }^{-}-\mathrm{N}$ ratio on the biomass of pak choi (Brassica chinensis). ${ }^{\text {a }}$ - the maximum fresh mass of every single plant in range of $\mathrm{NH}_{4}{ }^{+} 0-10 \mathrm{mM}, \mathrm{NO}_{3}{ }^{-} 5-15 \mathrm{mM}^{*}$ - statistically significant differences at 0.05 level.

\begin{tabular}{|c|c|c|c|c|}
\hline Treatment & $\begin{array}{l}\text { Ratio of } \mathrm{NH}_{4}^{+}-\mathrm{N} / \\
\mathrm{NO}_{3}{ }^{-}-\mathrm{N}\end{array}$ & Regression equation & $\begin{array}{l}\text { Coefficient of } \\
\text { correlation }\end{array}$ & $\begin{array}{l}\text { Maximum biomass } \\
{\left[\mathrm{g}(\mathrm{FM}) \text { per plant }^{\text {a }}\right.}\end{array}$ \\
\hline $\begin{array}{l}32 \% \text { full sunlight } \\
\text { with } 25 \mathrm{~g}(\mathrm{PEG} 6,000) \mathrm{L}^{-1}\end{array}$ & $\mathrm{NH}_{4}^{+}-\mathrm{N}$ & $\mathrm{y}=10^{(1.6447-0.0185 \mathrm{x})}$ & $r=-0.7556^{*}$ & 25.23 \\
\hline full sunlight without PEG 6,000 & $\mathrm{NH}_{4}{ }^{+}-\mathrm{N}$ & $y=62.374+5.247 x-0.871 x^{2}$ & $R^{2}=0.9997^{*}$ & 56.23 \\
\hline
\end{tabular}




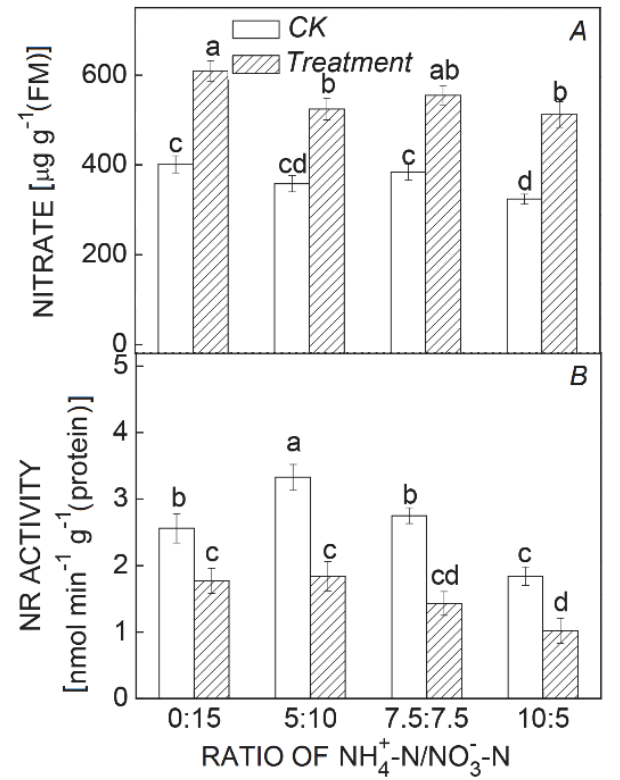

Fig. 2. Nitrate content and NR activity of pak choi leaves with different $\mathrm{NH}_{4}{ }^{+}-\mathrm{N} / \mathrm{NO}_{3}{ }^{-}-\mathrm{N}$ proportion. $\mathrm{CK}$ - full sunlight with no PEG 6,000; treatment: 32\% full sunlight with $25 \mathrm{~g}(\mathrm{PEG} \mathrm{6,000)}$ $\mathrm{L}^{-1}$. Lowercase letters mean statistically significant differences in 0.05 level $(P<0.05)$, the same in the following illustrations. $n=5$.
Pigment contents: At all $\mathrm{NH}_{4}{ }^{+}-\mathrm{N} / \mathrm{NO}_{3}{ }^{-} \mathrm{N}$ ratios, Chl $a$, $\mathrm{Chl} b$, total $\mathrm{Chl}$, and carotenoid (Car) contents exhibited great variations (Fig. $3 A-D$ ). Overall, nitrate- $\mathrm{N}$ increased pigment contents: as nitrate- $\mathrm{N}$ decreased and ammonium$\mathrm{N}$ increased, the pigment contents decreased. Under stress conditions at a $\mathrm{NH}_{4}{ }^{+}-\mathrm{N} / \mathrm{NO}_{3}{ }^{-}-\mathrm{N}$ ratio of $10: 5$, however, pigment contents increased suddenly. This change might be due to a sharp decline in biomass, which caused pigment contents to be increased to boost photosynthesis to compensate for the biomass loss caused by low light intensity. Under stress conditions, the content of $\mathrm{Chl} a$ relative to total $\mathrm{Chl}$ increased (Fig. $3 E$ ). When nitrate-N decreased and ammonium-N increased, the ratio of total Chl/Car increased (Fig. $3 F$ ). No statistically significant differences between biomass and $\mathrm{Chl}$ were detected (Table 2).

Photosynthetic capacity: At all ammonium/nitrate-N ratios, $P_{\mathrm{N}}, E$, WUE, $g_{\mathrm{s}}$, and $C_{\mathrm{i}}$ in the treated group $[32 \%$ full sunlight with $25 \mathrm{~g}(\mathrm{PEG} 6,000) \mathrm{L}^{-1}$ ] were lower than those of the control group (full sunlight with no PEG 6,000), whereas $L_{s}$ was higher (Fig. 4). As nitrate-N decreased and ammonium-N increased, $P_{\mathrm{N}}, E$, and $C_{\mathrm{i}}$ in the control group declined (Fig. 4A,D,E). $E$ first decreased slightly, then rose and subsequently declined (Fig. 4B),

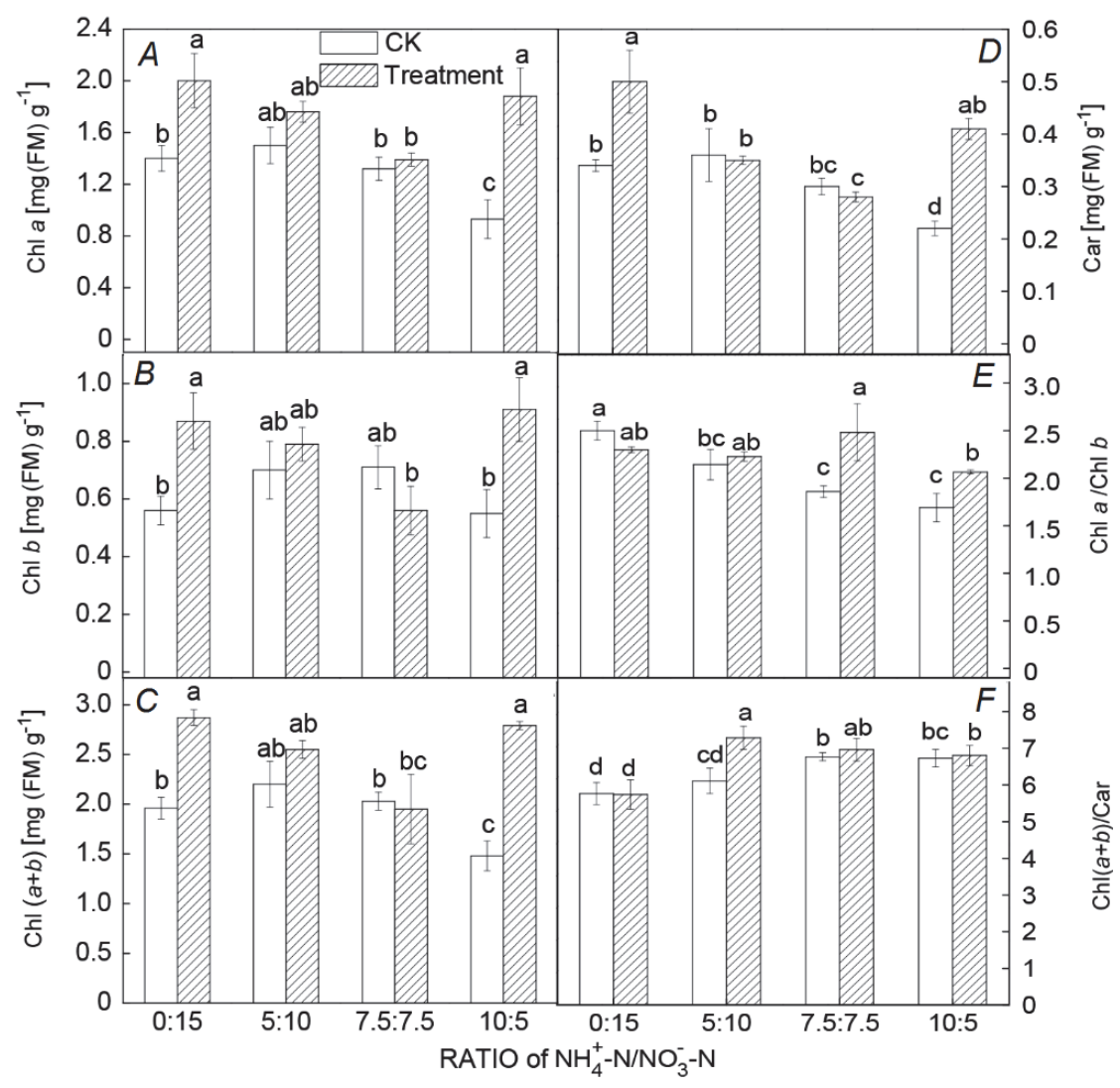

Fig. 3. Effects of $\mathrm{NH}_{4}{ }^{+}-\mathrm{N} / \mathrm{NO}_{3}{ }^{-}-\mathrm{N}$ ratio on chlorophyll (Chl) $a$, Chl $b$, Chl $(a+b)$, Car content, and Chl $a / b, \mathrm{Chl}(a+b) /$ Car proportion of Brassica chinensis leaves under low light intensity and water stress. CK - full sunlight with no PEG 6,000; treatment: $32 \%$ full sunlight with $25 \mathrm{~g}(\mathrm{PEG} 6,000) \mathrm{L}^{-1}$. Lowercase letters mean statistically significant differences in 0.05 level $(P<0.05)$, the same in the following illustrations. $n=5$. 
Table 2. Correlation between the biomass and chlorophyll fluorescence parameters, $\mathrm{Chl}(a+b)$ content, $\Phi_{\mathrm{PSII}}, \mathrm{NPQ}$, and $P_{\mathrm{N}}$ of $B$ rassica chinensis. $r$ - correlation coefficient; Sig. - significant level;*** - significant at 0.05 and 0.01 level, respectively.

\begin{tabular}{llllll}
\hline Variable & Parameter & Chl $(a+b)$ & $\Phi_{\text {PSII }}$ & NPQ & $P_{\mathrm{N}}$ \\
\hline Biomass [g(FM) per plant] & $r$ & -0.071 & $0.762^{*}$ & $-0.714^{*}$ & $0.833^{* *}$ \\
& Sig. & 0.867 & 0.028 & 0.046 & 0.01 \\
\hline
\end{tabular}

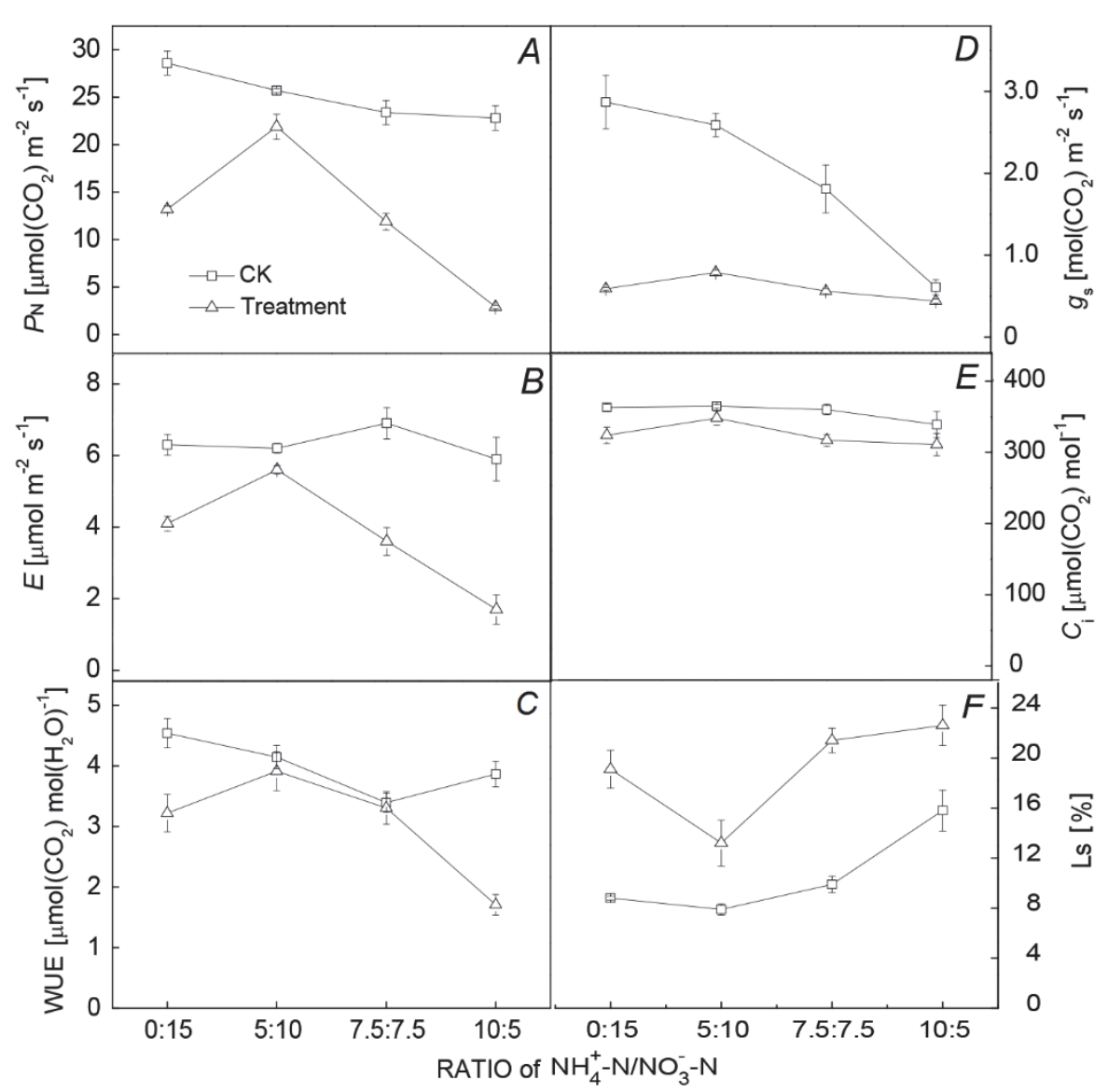

Fig. 4. Effects of $\mathrm{NH}_{4}{ }^{+}-\mathrm{N} / \mathrm{NO}_{3}{ }^{-}-\mathrm{N}$ ratio on net photosynthetic rate $\left(P_{\mathrm{N}}\right)$, transpiration rate $(E)$, intrinsic water-use efficiency (WUE), stomatal conductance $\left(g_{\mathrm{s}}\right)$, intercellular $\mathrm{CO}_{2}$ concentration $\left(C_{\mathrm{i}}\right)$, and stomatal limitation $\left(\mathrm{L}_{\mathrm{s}}\right)$ of Brassica chinensis leaves under low light intensity and water stress. CK - full sunlight with no PEG 6,000; treatment: $32 \%$ full sunlight with $25 \mathrm{~g}(\mathrm{PEG} 6,000) \cdot \mathrm{L}^{-1}$. Lowercase letters mean statistically significant differences in 0.05 level $(P<0.05)$, the same in the following illustrations. $n=5$.

while WUE and $\mathrm{L}_{\mathrm{s}}$ showed the upward trend after initial drop. WUE reached the lowest value at a $\mathrm{NH}_{4}{ }^{+}-\mathrm{N} / \mathrm{NO}_{3}{ }^{-}-\mathrm{N}$ ratio of 7.5:7.5 (Fig. 4C), and the minimum stomatal limitation was observed at a ratio of 5:10 (Fig. $4 F$ ). In the treated group, changes were regular, with a transition point occurring at a $\mathrm{NH}_{4}{ }^{+}-\mathrm{N} / \mathrm{NO}_{3}{ }^{-}-\mathrm{N}$ ratio of 5:10, except that $\mathrm{L}_{\mathrm{s}}$ (Fig. $4 F), P_{\mathrm{N}}, E$, WUE, $g_{\mathrm{s}}$, and $C_{\mathrm{i}}$ declined after an initial rise (Fig. $4 A-E$ ). $P_{\mathrm{N}}$ was the most important indicator of biomass, with an extremely significant correlation observed between both parameters in this experiment (Table 2).

\section{Discussion}

The $\mathrm{NH}_{4}{ }^{+}-\mathrm{N} / \mathrm{NO}_{3}{ }^{-}-\mathrm{N}$ ratio had a statistically significant effect on the biomass of pak choi (Table 1), with a
Chl fluorescence parameters: $\Phi_{\mathrm{PSII}}, \mathrm{ETR}$, and NPQ in the treated groups were lower than those of the control group at all ammonium/nitrate-N ratios (Fig. $5 C, D, F$ ), whereas $\mathrm{F}_{\mathrm{o}}, \mathrm{F}_{\mathrm{v}} / \mathrm{F}_{\mathrm{m}}$, and $\mathrm{q}_{\mathrm{p}}$ were largely unchanged (Fig. 5A,B,E). All Chl fluorescence parameters remained relatively stable for each ammonium/nitrate- $\mathrm{N}$ ratio in both control and treated groups. The relationships of biomass to $\Phi_{\mathrm{PSII}}$ and NPQ were statistically significant (Table 2).

substantial increase in the relative amount of ammonium$\mathrm{N}$ causing a sharp decrease in biomass (Fig. 1). 


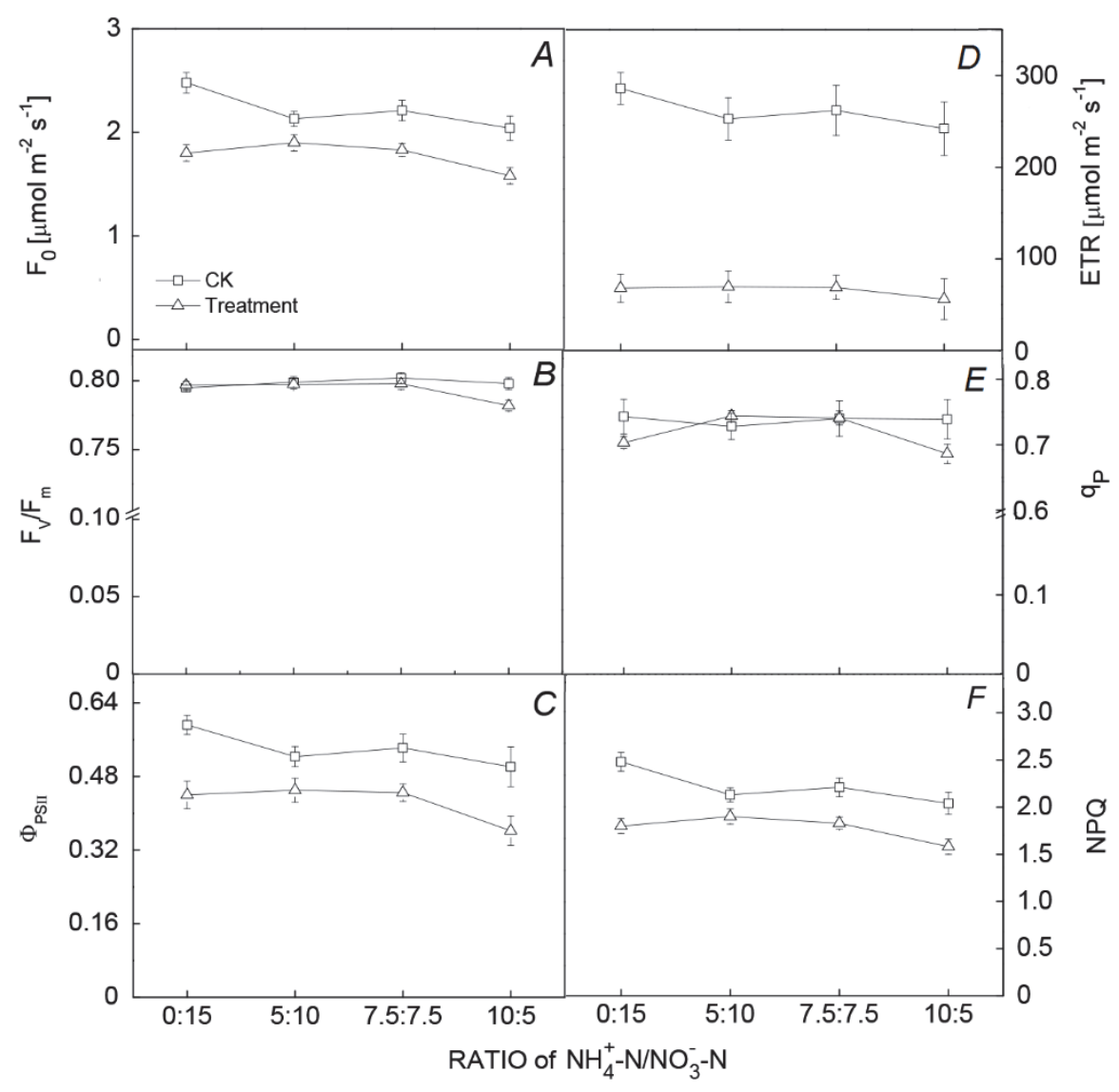

Fig. 5. Effects of $\mathrm{NH}_{4}{ }^{+}-\mathrm{N} / \mathrm{NO}_{3}{ }^{-}-\mathrm{N}$ ratio on minimum fluorescence $\left(\mathrm{F}_{0}\right)$, maximal quantum yield of PSII $\left(\mathrm{F}_{\mathrm{v}} / \mathrm{F}_{\mathrm{m}}\right)$, effective quantum yield of PSII photochemistry (ФPSII), electron transport rate (ETR), photosynthetic quenching (qP), and nonphotochemical quenching (NPQ) of Brassica chinensis under low light intensity and water stress. CK - full sunlight with no PEG 6,000; treatment: $32 \%$ full sunlight with $25 \mathrm{~g}(\mathrm{PEG} 6,000) \mathrm{L}^{-1}$. Lowercase letters mean statistically significant differences in 0.05 level $(P<0.05)$, the same in the following illustrations. $n=5$.

Since ammonium inhibits NR activity, most studies have found that the relationship between leaf photosynthetic rate and nitrogen supply follows a quadratic curve (Gill et al. 2011). When nitrogen supply or leaf nitrogen content reaches a certain value, the photosynthetic rate no longer increases (Zeng et al. 2000). In this study, the relationship between pak choi biomass and nitrogen supply under full sunlight without water stress followed a quadratic curve, whereas an exponential relationship was observed under $32 \%$ full sunlight with $25 \mathrm{~g}(\mathrm{PEG} 6,000) \mathrm{L}^{-1}$ (Table 1).

Since water deficit and light stress have a strong influence on pak choi leaf NR activity (Shen 2016), the addition of appropriate concentrations of ammonium in order to reduce nitrate uptake is an effective measure to reduce leaf nitrate content (Fig. 2). On the basis of high $\mathrm{NR}$ activity, the optimal $\mathrm{NH}_{4}{ }^{+}-\mathrm{N} / \mathrm{NO}_{3}{ }^{-}-\mathrm{N}$ ratio in this study was 5:10 (Fig. $2 B$ ). More nitrogen assimilation thus occurred at this ratio, and plants accumulated relatively higher biomass (Fig. 1) and relatively lower nitrate (Fig. 2A). This proportion of ammonium- vs. nitrate- $\mathrm{N}$ is therefore valuable as a reference point for agricultural production. Similar findings have been reported by Luo et al. (2005).

Under different experimental treatments, no significant correlation was found between the Chl content and biomass (Table 2), but an obvious correlation was observed between $\Phi_{\text {PSII }}$ and pak choi biomass. NPQ and pak choi biomass were obviously negatively correlated, and the correlation between pak choi biomass and $P_{\mathrm{N}}$ reached an extremely significant level (Table 2). These results demonstrated that a relationship exists between biomass accumulation and solar energy utilization in plants, with biomass and $P_{\mathrm{N}}$ the most closely related. No correlation was found between the Chl content and yield, which rules out the use of the Chl content as an indicator of crop photosynthetic capability or biomass accumulation. For comprehensive assessment, all the above factors must be taken into account.

Studies have shown that a decline in $P_{\mathrm{N}}$ under drought stress is the result of both stomatal and nonstomatal limitations. Under mild stress, the decline is mainly due to stomatal limitation, whereas nonstomatal limitation is a more important contributor under severe stress (Guan et al. 1995). In this study, $P_{\mathrm{N}}$ was positively correlated with $C_{\mathrm{i}}$ 
(Fig. 4A,E), $\mathrm{L}_{\mathrm{s}}$ was negatively correlated with both $g_{\mathrm{s}}$ and $C_{\mathrm{i}}$ (Fig. $4 D-F$ ), and $P_{\mathrm{N}}$ was significantly negatively correlated with $\mathrm{L}_{\mathrm{s}}$ (Fig. $\left.4 A, F\right)$. These results indicated that the main reason for a decline in $P_{\mathrm{N}}$ was the stomatal limitation. Chl fluorescence parameters can reflect the series of critical adjustment processes in photosynthetic organs (Wu et al. 1997). In this study, ETR was positively correlated with $\Phi_{\mathrm{PSII}}\left(\right.$ Fig. $5 C, D$ ), and $\mathrm{q}_{\mathrm{P}}$ was positively correlated with NPQ (Fig. 5E,F). An improvement in $\mathrm{q}_{\mathrm{P}}$ due to increased concentrations of ammonium-N can increase the proportion of open PSII reaction centers, thus improving PSII electron transfer ability, while NPQ reflects the radiation energy dissipation capacity of the PSII reaction center. The level of $\mathrm{q}_{\mathrm{P}}$ is maintained by adjustment of NPQ, thus ensuring consistency of electron transfer and $\mathrm{CO}_{2}$ fixation rates. This phenomenon explains why increasing $\mathrm{NH}_{4}{ }^{+}-\mathrm{N}$ initially improved $\mathrm{q}_{\mathrm{P}}$, with further increases causing $\mathrm{q}_{\mathrm{P}}$ to decline.

Water influences plant photosynthetic capacity mainly through indirect effects on factors limiting photosynthesis. Plant leaves under well-watered conditions have stronger photosynthetic capacity, with water deficit causing photosynthetic rates to decrease obviously. Various hypotheses have been advanced to explain why water deficit attenuates photosynthesis. Some researchers have proposed that water deficit decreases photosynthetic rate primarily by reducing stomatal conductance (i.e., increasing stomatal resistance), thus affecting $\mathrm{CO}_{2}$ transport into leaves (Guan et al. 1995, Fukutoku 1996) such that blades hydrolyze more starch, accumulate sugars, and experience slowed photosynthetic product output (Saglio and Pradet 1980, Guan et al. 1995). In the present investigation, the positive correlation of $E$ with $P_{\mathrm{N}}$ (Fig. $\left.4 A, B\right)$ and $E$ with $g_{\mathrm{s}}$ (Fig. $4 B, D$ ) might cause WUE to increase under water stress. Under our experimental conditions of reduced light intensity and high nitrate and ammonium, however, WUE was relatively low (Fig. 4C). This observation suggests that even under low light conditions, proper adjustment of

\section{References}

Ai S.Y., Yao J.W., Huang X.H. et al.: [Study on the nitrate reduction characteristic of vegetables.] - Plant Nutr. Fertil. Sci. 8: 40-43, 2002. [In Chinese]

Angus J.F., van Herwaarden A.F.: Increasing water use and water use efficiency in dryland wheat. - Agron. J. 93: 290-298, 2001.

Brittain Jr. G.D.: Managing drought stress in California agricultural systems. PhD. Thesis, University of Nebraska, Lincoln 2016.

Cramer M.D., Hawkins H.J., Verboom G.A.: The importance of nutritional regulation of plant water flux. - Oecologia 161: 1524, 2009.

De Las Rivas J., Abadía A., Abadía J.: A new reversed phaseHPLC method resolving all major higher plant photosynthetic pigments. - Plant Physiol. 91: 190-192, 1989.

Deng X.P., Shan L., Zhang H. Turner N.C.: Improving agricultural water use efficiency in arid and semiarid areas of China. - Agr. Water Manage. 80: 23-40, 2006.
ammonium-N and nitrate-N can improve WUE.

Nitrogen, one of the most important nutritional elements required by plants, is also the most common factor limiting plant growth. Plants using the $\mathrm{C}_{3}$ pathway, the main plant photosynthetic physiological metabolic process on the Earth, have a leaf nitrogen content of $75 \%$. In $\mathrm{C}_{3}$ plants, this leaf nitrogen is used in chloroplast physiological processes, mostly photosynthesis, consequently, nitrogen often becomes the limiting factor of plant growth (Luo et al. 2005). Fluctuations in plant nitrogen nutrition directly affect photosynthetic rate and growth and development, and, ultimately, biomass and light energy utilization. Studies have shown that application of ammonium- and nitrate- $\mathrm{N}$ has a positive effect on most crops. Mixed application of nitrate- and ammonium$\mathrm{N}$ fertilizers is able to reduce vegetable $\mathrm{NO}_{3}{ }^{-}$content and increase vitamin $\mathrm{C}$ content, with the optimum ratio depending on crop growth period (Huang et al. 2011). Under the treatment conditions of our study, $P_{\mathrm{N}}, E, \Phi_{\mathrm{PSII}}$, and ETR first increased and then decreased, with the maximum values occurring at the lowest content of $\mathrm{NH}_{4}{ }^{+}-$ $\mathrm{N}(5 \mathrm{mM})$. Chl $a, \mathrm{Chl} b$, and Chl $(a+b)$ contents initially decreased and then increased (Fig. $3 A-C$ ). At a $\mathrm{NH}_{4}{ }^{+}-\mathrm{N} /$ $\mathrm{NO}_{3}{ }^{-} \mathrm{N}$ ratio of $10: 5$, pigment contents increased suddenly, possibly because of a sharp decline in biomass. The resulting increase in pigment contents enhanced photosynthetic processes to compensate for the loss of biomass due to low light intensity.

Conclusion: The results of our study imply that the relative proportions of ammonium- and nitrate-nitrogen affect biomass accumulation in water-deficient and low lightintensity environments as well as under nonstressed conditions and all have a positive correlation to biomass. At the same time, we observed no correlation between biomass and chlorophyll contents. Biomass accumulation positively correlated with $\Phi_{\mathrm{PSII}}$ and $P_{\mathrm{N}}$, but negatively correlated with NPQ.

Fukutoku J.: Effect of water stress on nitrate assimilation in soybean leaves. - Bull. Faculty Agr. Saga Univ. 80: 69-76, 1996.

Gigon A., Rorison I.H.: The response of some ecologically distinct plant species to nitrate-and to ammonium-nitrogen. - J. Ecol. 60: 93-102, 1972.

Gill S.S., Khan N.A., Anjum N.A. et al:: Amelioration of cadmium stress in crop plants by nutrients management: morphological, physiological and biochemical aspects. - Plant Stress 5: 1-23, 2011.

Guan Y.X., Dai J.Y., Lin Y.: [The photosynthetic dtomatal and nonstomatal limition of plant leaves under water stress.] - Plant Physiol. Comm. 31: 283-297, 1995. [In Chinese]

Hirel B, Tétu T, Lea P.J. et al.: Improving nitrogen use efficiency in crops for sustainable agriculture. - Sustainability 3: 14521485, 2011.

Hou X., Li J.F., Xu X.Y.: [Effects of low light on morphological 
and physiological indexes of tomato at different growth stages.] - Acta Hort. Sin. 29: 123-127, 2002. [In Chinese]

Huang J., Zhou X.Y., Liu L.: [Effects of $\mathrm{NH}^{+}-\mathrm{N} / \mathrm{NO}^{-}-\mathrm{N}$ ratio on pak-choi nitrogen metabolism and enzyme activity under weak-light.] - Chin. J. Eco-Agr. 19: 783-787, 2011. [In Chinese]

Kuang S.B., Zhang G.H., Chen Z.J. et al.: [Change in morphological and growth indexes of Panax notoginseng seedling under different light conditions.] - J. Plant Resour. Environ. 23: 54-59, 2014. [In Chinese]

Lastra O., Tapia M.L., Razeto B. et al.: [Response of hydroponic lettuce cultivars to different treatments of nitrogen: growth and foliar nitrate content.] - Idesia (Arica) 27: 83-89, 2009. [In Spanish]

Leleu O., Vuylsteker C., Têtu J.F. et al.: Effect of two contrasted $\mathrm{N}$ fertilisations on rapeseed growth and nitrate metabolism. Plant Physiol. Bioch. 38: 639-645, 2000.

Luo J.K., Chen W., Zhang P.W. et al.: Mechanism of nitrate accumulation of Chinese cabbage under properly enhanced ammonium. - Plant Nutr. Fertil. Sci. 11: 800-803, 2005. [In Chinese]

Maroco J.P., Rodrigues M.L., Lopes C. et al.: Limitations to leaf photosynthesis in field-grown grapevine under droughtmetabolic and modelling approaches. - Funct. Plant Biol. 29: 451-459, 2002.

Michel B.E., Kaufmann M.R.: The osmotic potential of polyethylene glycol 6000. - Plant Physiol. 51: 914-916, 1973.

Oerke E.C., Dehne H.W., Schönbeck F. et al.: Crop Production and Crop Protection: Estimated Losses in Major Food and Cash Crops. Pp. 484-513. Elsevier Science B.V., Amsterdam 1994.

Ruiz-Martinez A., Garcia N.M., Romero I. et al.: Microalgae cultivation in wastewater: nutrient removal from anaerobic membrane bioreactor effluent. - Biores. Technol. 126: 247253, 2012.

Saglio P.H., Pradet A.: Soluble sugars, respiration, and energy charge during aging of excised maize root tips. - Plant Physiol. 66: 516-519, 1980.

Schreiber U., Schliwa U., Bilger W.: Continuous recording of photochemical and non-photochemical chlorophyll fluores- cence quenching with a new type of modulation fluorometer. Photosynth. Res. 10: 51-62, 1986.

Shen G.M.: Variety types of nitrogen and light levels on Brassica chinensis yield and quality parameters under water stress. Commun. Soil Sci. Plan. 47: 1721-1730, 2016.

Vyas S.P.: Influence of light intensity on growth, yield and lawsone content of Henna (Lawsonia inermis L.). - Ind. J. Plant Physiol. 9: 275-277, 2004.

Wang J., Zhou Y., Zhou C. et al.: Effects of $\mathrm{NH}_{4}{ }^{+}-\mathrm{N}^{-\mathrm{NO}_{3}}{ }^{-} \mathrm{N}$ ratios on growth, nitrate uptake and organic acid levels of spinach (Spinacia oleracea L.). - Afr. J. Biotechnol. 8: 36153622, 2009.

Waraich E.A., Ahmad R., Ashraf M.Y. et al.: Improving agricultural water use efficiency by nutrient management in crop plants. - Acta Agr. Scand. S. B-S. P. 61: 291-304, 2011.

Wu H., Zhang S.Y., Xu D.Q. et al.: [Diurnal and seasonal variations of non-photochemical quenching of chlorophyll fluorescence in sweet Viburnum leaves.] - Acta Phytophysiol. Sin. 23: 145-150, 1997. [In Chinese]

Xu Z.Z., Zhou G.S.: Effects of water stress and high nocturnal temperature on photosynthesis and nitrogen level of a perennial grass Leymus chinensis. - Plant Soil 269: 131-139, 2005.

Xu Z.Z., Zhou G.S.: Combined effects of water stress and high temperature on photosynthesis, nitrogen metabolism and lipid peroxidation of a perennial grass Leymus chinensis. - Planta 224: 1080-1090, 2006.

Yan X., Jin J., He P. et al.: Recent advances on the technologies to increase fertilizer use efficiency. - Agr. Sci. China. 7: 469479, 2008.

Yu Y., Yang Q., Liu W.: [Spectral absorbance, yield and quality responses of three leaf-color lettuces to various nitrogen forms supply.] - Acta Agr. Boreali-Sin. 30: 425-428, 2015. [In Chinese]

Zeng X.B., Qing C.L., Xie D.T. et al.: [Interrelationship of light and nitrogen fertilizer application in crop growth.] - Acta Pedol. Sin. 37: 380-387, 2000. [In Chinese]

Zhang P.W., Chen W., Xue F. et al.: [Effects of increasing ammonium rate on growth of pak choi.] - Acta Pedol. Sin. 44: 901-906, 2007. [In Chinese] 